\title{
The Improvement of English Skills for Islamic Junior High School Teachers Using ESA (Engage Study Activate) Approach
}

\author{
Author \\ Ikhrom, Ruswan, \& Sayyidatul Fadlilah \\ Correspondence \\ UIN Walisongo Semarang \\ ikhrom@walisongo.ac.id, r_thoy@yahoo.co.id, sayyidatulfadlillah@gmail.com
}

\begin{abstract}
Language is a skill that insists approach and certain strategy to master it. ESA (Engaged-Study-Activate) is an approach used in learning foreign language based on the theory that the success of learning language is determined by the factor of involvement in learned language environment. Therefore, the ideal way of learning language is that it is done in the country in which the language is used as the first language. When it is difficult to be achieved, it needs the availability of artificial learning atmosphere that gives situation as if the students are in English speaking community. This training needed three main activities: involvement, study, and language-based activities. By using those three main activities, the program of English skill improvement for the teachers of Islamic Junior high school in Tugu and Ngaliyan District was held. The result of the study through guidance shows that participants' English skills increased. Although it is not too significant, the improvement of their English skills proves that ESA approach was appropriate to be used to maximize participants' learning achievement. Its less significance was caused by several factors, they are: learning activities (offline learning) was held in every Friday, at the time teachers had felt tired. The offline program was also only held once a week although they were facilitated with online learning program. Another important factor that must be considered is that the teachers had many other activities related to their Islamic social organization activity. However, they still had high motivation in joining the program. They also had a good commitment to learn English. This factor had good effect towards the learning achievement improvement although it is not too high.
\end{abstract}

Keywords: ESA (engaged study activate), English speaking community, hybrid strategy

Received: 15 December 2017. Accepted: 15 January 2018

\section{INTRODUCTION}

Mastery of English language skills is an essential requirement for any teacher, regardless of the subjects he teaches. This also applies to teachers in Madrasah Tsanawiyah at Tugu and Ngaliyan sub-districts. This foreign language is necessary because it can assist teachers in developing good insights relating to the development of knowledge in accordance with the subjects they are enabling or to obtain other knowledge beyond their core competencies.

It can be portrayed that the teachers' English grammar skills were low. They cannot express their thought, feelings, willing, or report the facts in the broader scope. Moreover, the teacher cannot develop their idea cohesively.

The basis of thinking can be described as follows. As an international language, English becomes a language of great interest, as well as the development of technology and business is dominated by English language. The language that is installed on hardware and software technology is also in English. It certainly requires teachers, regardless of their subject matter, to master English to communicate with people around the world. In this case, it is related in academic field.

If the teachers do not have the ability as mentioned above, the teacher will experience various difficulties daily communication. As teachers - including madrasah teachers, they will have difficulty in developing learning materials to learners if their reading skills are inadequate. Considering that a small amount of Islamic studies material is currently written in various local, national, and international journals using English. On the other hand, the students will experience boredom in attending the lessons delivered by the teacher, because updating information that brought his teacher tends to stagnate.

Madrasah teachers are also challenged to have good listening skills, given the information about Islam is also quite swiftly delivered through television not only in the Indonesian language. In fact, many programs have been delivered in English. Though the news or information contains a lot about the nuances of Islam. Further, if madrasah teachers do not have good listening skills, then the understanding and absorption of Islamic information through radio and television news cannot be acquired optimally. The inability to read English texts will also have a very serious impact on the development of an understanding of Islamic studies. Reading skills are an active-receptive skill. Active reading skills when a person passes information to other people by reading their own writing or others. So reading in this category is considered as active reading activity. Meanwhile reading other people's works can be categorized into the receptive reading skills. Thus, the first type of reading skill is a skill to convey ideas, ideas, thoughts, and feelings through speaking skills.

Furthermore, non-English teachers (including madrasah teachers) also need speaking skills in English 
(speaking skills). Speech skills are known to be three types of speaking situations, namely interactive, semiinteractive, and non-interactive. Interactive speaking situations, for example, occur in face-to-face conversations and talk over the phone. Activity speaking in this interactive situation allows for a change of role / activity between speaking and listening. In addition, this interactive situation allows communication actors to ask for clarification, repetition of words / phrases, or to ask the other person to slow down the speech tempo, and so on. The activity of speaking in an interactive situation is done face-to-face, two-way, or even multidirectional.

Then, there is also semi-interactive speaking situations, for example in public speaking, campaigns, sermons / lectures, etc., whether it is done through faceto-face or one-on-one. In this situation, the audience can not interrupt the conversation, but the speaker can see the audience's reaction from their facial expressions and body language.

Some speaking situations can be said to be noninteractive if the conversation is in one direction and not through face-to-face, such as radio or television. State speeches delivered on television or radio are included in this type.

To apply the three forms of English speaking skills interactive, semi interactive and non-interactive - is a challenge for non-English teachers today and in the future. The rapid growth of social media in the form of WhatsApp, Facebook, Instagram, Twitter, Messenger, E-mail, Telegram, and so on requires the teachersability in English be more proficient in delivering oral or oral Islamist messages in English version.

The importance of English proficiency for all teachers is based on the reality that many reading sources covering various disciplines - including studies of Islamic education, Islamic faith, and other religious studies - are written in English. Various written scientific information in English is poured in the form of books, journals, newspapers or magazines or the internet. These conditions necessarily require teachers to be able to speak English well. How a teacher can develop his or her scientific knowledge, how the teacher's professional competence (subject matter competency) can be improved, and how the expansion and updating of his Islamic knowledge, if his English proficiency is lacking.

Even the need for mastery of English skills increases when the teacher must complete his or her study at the level of master or even doctor program. Scientific books for both general studies and many Islamic studies are written in English. Besides, the development of Semarang that leads to Metropolis City where the society is increasingly multi ethnic and many foreign people from English speaking countries come to this city and it demands the teacher to be able to communicate fluently in English.

The need of English language mastery has not been met by the majority of Madrasah Tsanawiyah teachers in Tugu and Ngaliyan sub-districts in particular, and in the city of Semarang in general. It is none other than because of the weak English language ability of the teachers. They have made efforts to improve their
English skills, but because of the approach of learning English is not right, then the results have not been maximized.

At least they have "studied" or are more accurately said to have encountered English subjects for 6 years in school, and take 4 to 6 credits during college. The length of time this "study" did not make them skilled in English. Their mistake in learning English lies in the learning approach they use. Their English treats more as "knowledge" than as "skill".

They rarely or even never use English as a medium to communicate in their daily routines. English is studied only as knowledge of grammar and knowledge of the meaning of vocabularies. Eventually English remains a "foreign language" even though it has been studied for years.

ESA (Engaged-Study-Activate) is an English learning approach that requires the involvement of learners in English-speaking situations. Four language skills are learned in a natural way, by putting the learner into the "get involved" situation. Learners live in an English-speaking environment, listen to people who speak English, read English writing books and resources, speak English and write in English.

Implementation of ESA in an effort to improve the English language skills proved a lot. Information on the truth is based on many research results. A study that examines the effect of ESA methods on students' speaking skills on learning English. This experimental research was conducted in Tasikmalaya City. The results show that the application of ESA method is effective in improving English speaking skills. Denik Ngaisyatul Munawaroh's research \& Sumardiono also explained that the ESA method can improve writing skills (writing skills), especially in writing descriptive texts. Even the findings confirmed, ESA method not only able to improve the score of student learning outcomes, but also improve their learning motivation. Observational data explains that students are more active, enthusiastic, and actively involved throughout the learning process. With ESA's approach "English" study is something functional, not making it up. "Study" is the way to solve problems that arise in the process of engaging. Engagement and study are two things that are intertwined (inseparable). Thus the process of activating the "knowledge and skills" that have been obtained through the "study" continues with the involvement of learners in a continuous English situation.

On the basis of reality and also the rationality above, this article is focused on elaborating the improvement of English proficiency in four aspects including listening, speaking, reading and writing skills with ESA (Engaged-Study-Activate) approach.

\section{Method}

This article is a result of the work of research-based lecturers. The study was conducted using a qualitative approach with a collaborative participatory model. This model is meant that data mining activities are conducted through collaborative engagement and activeness of the participants and the speakers. Such learning models are carried out in the context of implementing an ESA (engaged-study-activate) approach that emphasizes 
three important aspects of learning, namely, encouragement, motivation, and opportunity.

The application of ESA's approach to learning activities is summarized as follows. Elements of Engage, Study, and Activate in practical level is not a sequence in learning activities or linguistic activities in the classroom. The three elements can be alternated. But conceptually the teacher, first try to make learners focus and motivated to follow learning (Engage), then they study something related with language or information contained in text (Study), then learners try to apply what has been studied at element of Study into the form of exercises (Activate). Application of ESA approach can be formulated in the form of diagram as below.

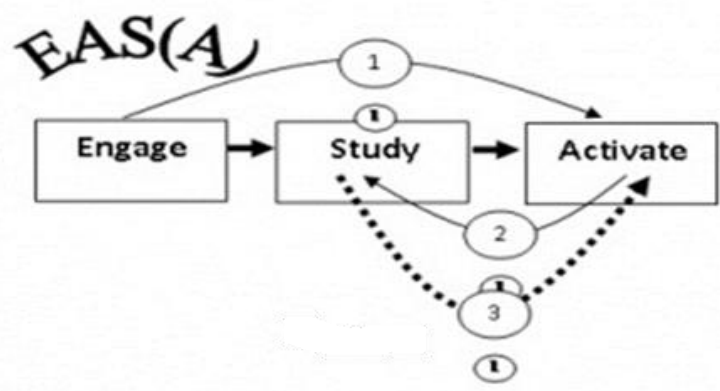

Figure 1. ESA Cycle

The picture above illustrates the application of ESA elements in learning that are not always in sequence. English Proficiency Improvement Activities with ESA Approach for Madrasah Tsanawiyah Teachers in Kecamatan Tugu and Ngaliyan Semarang City lasted for 2 (two) months. That is since July 7, 2017 until September 8, 2017. The program took place in the English Language Laboratory Faculty of Tarbiyah and Teacher Training of Walisongo State Islamic University of Semarang. Participants were 25 people consisting of 19 men and 6 women.

In the implementation of this activity involves various parties include:

1. Head of Madrasah Tsanawiyah in Tugu and Ngaliyan Subdistricts They are asked to be able to assign teachers who are interested in training. They are also required to be able to monitor teacher progress in English mastery.

2. Teachers from 5 (five) Madrasah Tsanawiyah with around 25 people ( 5 people from each madrasah).

Board of PERGUNU (Nahdlatul Ulama Teachers Association) Semarang City. They were asked to help mapping the competence of Madrasah teachers in Tugu and Ngaliyan sub-districts.

The activities of increasing English Language Ability is done in several stages as follows:

1. Mapping training needs

As described in the preliminary, before the training activities took place the team conducted a survey by distributing questionnaires to teachers of Madrasah Tsanawiyah Tugu and Ngaliyan Semarang City. This survey is intended to measure teachers' interest in English training. Also intended to know aspects of English skills that are desired to be improved: listening, speaking, reading or writing.
The survey results show that teachers of Madrasah Tsanawiyah in Tugu sub-district and Ngaliyan sub-district of Semarang are interested in English language training, especially speaking and TOEFL training.

2. Search sources

After the mapping the distribution of English Proficiency with ESA Approach for Madrasah Tsanawiyah Teachers in Tugu and Ngaliyan Subdistricts Semarang City, the next step is looking for competent resource person and ready for the training. Finally the team got two speakers namely Agus Prayogo, M.Pd. and Muhammad Jauhari Sofi, M.A. Both speakers were selected with consideration of the competencies concerned. In addition, the two speakers understand and master the ESA approach and its application strategy in English learning activities.

Agus Prayogo is an alumnus of S.1 of English Study Program of Faculty of Tarbiyah IAIN Walisongo and Degree Program of S.2 English State University of Semarang. Agus Prayogo is also an alumnus of a student training program for students in the United States that lasts for 1 (one) month. Meanwhile, Muhammad Jauhari Sofi is an alumnus of S.1 of the English program of the Faculty of Tarbiyah IAIN Walisongo and the S.2 English Language Program of Uthman University of India. Both speakers also have teaching experience at UIN Walsongo and also at private universities around Semarang.

\section{Looking for Program venue}

In order to ensure that the activity works well, the team is looking for eligible activities. During the training, at least one cooled room (AC) is required, there is an audio facility and is easily accessible by the participants. Therefore, it is determined that the place of activity in Language Laboratory of English Education Studies Program Faculty of Tarbiyah and Teacher Training, located on Jl. Prof. Hamka Campus II UIN Walisongo Semarang.

\section{Preparing training materials and strategies}

Based on the survey results, the Team decided what materials would best suit the needs of the trainee's teachers. The team then discussed the training materials including materials for improving speaking skills, listening skills materials, reading comprehension skills, writing skills enhancement and skills enhancement materials for TOEFL (Test of English as Foreign Language)

In addition, the team also discussed how appropriate training strategies to train teachers in improving their English skills. It is known that the participants of this training are teachers whose initial abilities in various English speakers. Some participants have good initial competence. While the other abilities initially very low. All activities are designed to facilitate all teachers' learning needs in order to avoid boredom and passive class. 


\section{Pre-test}

This pre-test is done to determine the initial ability of the English trainee. For the pre-test use, the TOEFL test is administered. The resource person distributes the TOEFL test sheet then the test is done begins with listening, followed by structure and reading comprehension.

\section{Learning contract}

At the inaugural meeting the Team entered into a learning contract / training contract with the participants. The contract covers what participants should do during the two-month training period.

In the learning contract process it is agreed that the trainees should do the following:

a. Be punctual on off line tutorials

b. Active in the training process

c. Actively commented in WA group

d. Perform all tasks assigned by the resource person and / or Team

Delivering a permit request when forced to leave for reasons that can be justified. Conversely, the participants will also obtain:

a. Get training materials

b. Get accommodations' fees

c. Get a training certificate

\section{Technical Explanation of KPD}

In the first meeting the participants get an overview and introduction of the activities of English language improvement with ESA Approach for Madrasah Tsanawiyah Teachers in Tugu and Ngaliyan Subdistricts of Semarang City. Head of the team also explain that this program is part of community engagement program UIN Walisongo, especially the community around the campus. KPD is intended to improve the English proficiency of teachers, especially those in Madrasah. The KPD team saw that the English proficiency of Madrasah Tsanawiyah teachers was very low. Though English language skills are very necessary at this time where English is used massively in various fields and for various purposes. For teachers English can be a tool to open the treasury of information and scholarship in various fields.

The KPD team also explained the technical implementation of the training. Further, it is also explained that the failure of learning English because the learner is not actively involved in the learning process. Engagement in the English environment that became the key to success in learning English. Ideally those who study English live or live in a community that speaks English but not everyone has a chance to be in that kind of environment.

Usually Indonesian students know English when they are already in junior high school level. Since then they have learned English at least 2 (two) hours of lessons a week. Thus, students in Indonesia have a lot of opportunities to learn English. During the first three years of junior high school, three years in high school, plus at least 2 credits / one semester Indonesian students receive English subjects/ courses. But why very few children are able to communicate in English. There must be something wrong in the process of learning English. The fault is that they do not involve themselves in the process of communicating in English. As a result, English continues to be a foreign language, although Indonesian students are studying for years.

The English Language Improvement Activity with ESA Approach for Madrasah Tsanawiyah Teachers in Tugu and Ngaliyan Subdistricts in Semarang City emphasizes the involvement of trainees. They will be conditioned to engage in group training communications through WA facilities (WhatsApp) and through face-to-face meetings with facilitators who are conditioned to use English during the course of the training.

\section{TOEFL Practices}

TOEFL exercises are at the core of direct trainee activities with resource persons. It lasts for 8 (eight) times. At the second meeting the speakers gave an explanation of the tips of success in TOEFL. It is known that TOEFL has its own characteristics. Those who are proficient in English are not necessarily proficient in TOEFL. As a test with a specific model, TOEFL requires certain techniques for completion related to listening, structure and reading.

\section{Online tutoria}

One of the highlights of this training is the use of WhatsApp social media to interact between resource persons and participants and between participants and participants. This educational interaction has proven to be very beneficial for efforts to improve English-language abilities.

Technically it can be explained that the KPD Team or resource person sends an order or conveys certain issues to be addressed. Once there is a response from the participants, the Team or resource person provides comments, answers or improvements to the participants' comments mainly from the grammatical side. In the early stages, functional theory is emphasized, that the functional aspects of communicating in English are far more important than the emphasis of grammatical elements and pronunciation. Let them actively engage in discussions using English. Avoid a lot of corrections, because it can make them afraid and wary of speaking English. This is similar to Hayriye Kayi's phrase, "do not correct students' pronunciation mistakes very often while they are speaking"'. Correction should not distract the student from his or her speech.

\section{Post-test}

This post-test is performed to determine the final capability of the English trainee. For the post-test use TOEFL test. The resource person distributes the TOEFL questionnaire, then the test begins with listening, followed by structure and reading comprehension. Comparison of pre-test results with post-test results is used to determine and measure 
the success rate of research-based mentoring activities.

\section{Results and Discussion}

In general, mentoring activities to improve the English proficiency of madrasah Tsanawiyah teachers in Tugu and Ngaliyan sub-districts of Semarang City can run well. Viewed from the process side, the learning process can be done through collaborative participatory model in accordance with ESA approach. However, in terms of results have not been satisfactory yet because there is no significant increase. This can be seen from the average TOEFL score on pre-test. This pre-test is done to determine the initial ability of the English trainees. The resource person distributes the TOEFL questionnaire, then the test begins with listening, followed by structure and reading comprehension.

After the calculation can be calculated TOEFL results as follows:

Table 1. Pre-Test Score (TOEFL)

\begin{tabular}{llcccc}
\hline No & Initial & Lit & Struct & Read & Sum \\
\hline 1 & ZM & 450 & 500 & 430 & 460 \\
2 & MF & 300 & 370 & 310 & 326 \\
3 & ADS & 480 & 510 & 530 & 506 \\
4 & SYA & 370 & 460 & 360 & 396 \\
5 & NQ & 320 & 470 & 400 & 396 \\
6 & HN & 370 & 380 & 480 & 410 \\
7 & DSN & 540 & 540 & 550 & 543 \\
8 & NF & 430 & 480 & 450 & 453 \\
9 & R & 380 & 310 & 310 & 333 \\
10 & RUH & 410 & 350 & 400 & 386 \\
11 & MAS & 370 & 330 & 280 & 326 \\
12 & J & 450 & 360 & 300 & 370 \\
13 & S & 370 & 450 & 460 & 427 \\
14 & MS & 470 & 600 & 490 & 520 \\
15 & NH & 440 & 380 & 370 & 397 \\
16 & NM & 480 & 400 & 290 & 390 \\
17 & M & 350 & 250 & 350 & 317 \\
18 & KF & 370 & 380 & 310 & 345 \\
19 & AF & 350 & 360 & 340 & 350 \\
20 & D & 480 & 510 & 450 & 480 \\
21 & UR & 480 & 400 & 290 & 390 \\
22 & EWM & 500 & 330 & 310 & 380 \\
23 & IRH & 370 & 310 & 400 & 360 \\
24 & AM & 370 & 380 & 280 & 343 \\
25 & S & 420 & 400 & 310 & 377 \\
\hline & Means & 413 & 408 & 378 & 399 \\
\hline & & & & &
\end{tabular}

From this pre-test it is known that the highest TOEFL score of this training participant is 543 whereas the lowest score is 317 . The average TOEFL score is 399. Obtaining scores on each aspect of TOEFL are as follows:

- Listening: 413

- $\quad$ Structure: 408

- Reading comprehension: 378

From the pre-test is also known that the participants have different competencies. Disparity between the highest and the lowest is too far. Meanwhile, the reading aspect occupies the lowest position in the acquisition score, while listening aspect occupies the highest position in the acquisition score.
After the course runs two months and according to the schedule that has been submitted to the participants then on Friday, 31 August 2017 held post-test with the TOEFL test. The participants' TOEFL score is as follows:

Table 2. Post-Test Score (TOEFL)

\begin{tabular}{clcccc}
\hline No & Initial & List & Struct & Read & Sum \\
\hline 1 & J & 450 & 360 & 300 & 370 \\
2 & ZM & 460 & 470 & 430 & 453 \\
3 & MF & 420 & 400 & 310 & 377 \\
4 & ADS & 530 & 610 & 530 & 557 \\
5 & S & 370 & 450 & 460 & 427 \\
6 & SYA & 470 & 410 & 360 & 413 \\
7 & MS & 470 & 600 & 490 & 520 \\
8 & NH & 440 & 420 & 370 & 397 \\
9 & NQ & 420 & 380 & 400 & 397 \\
10 & HN & 510 & 420 & 480 & 470 \\
11 & DS & 610 & 610 & 550 & 590 \\
12 & NF & 480 & 510 & 450 & 480 \\
13 & NM & 480 & 400 & 290 & 390 \\
14 & R & 500 & 330 & 310 & 380 \\
15 & RUH & 370 & 345 & 400 & 360 \\
16 & MAS & 370 & 380 & 280 & 343 \\
17 & M & 350 & 250 & 350 & 317 \\
18 & KF & 370 & 380 & 310 & 345 \\
19 & AF & 350 & 380 & 340 & 350 \\
20 & D & 480 & 510 & 450 & 480 \\
21 & UR & 480 & 400 & 450 & 390 \\
22 & EWM & 500 & 345 & 350 & 380 \\
23 & INH & 370 & 382 & 400 & 360 \\
24 & AM & 370 & 380 & 280 & 343 \\
25 & S & 420 & 400 & 370 & 377 \\
\hline & Means & 442 & 421 & 388 & 411 \\
\hline
\end{tabular}

From this post-test it is known that the highest TOEFL score of the trainees is 557, while the lowest score is 317 . The average TOEFL score is 411 . The score on each aspect of the TOEFL is as follows:

- Listening: 442

- Structure: 421

- Reading comprehension: 388

As explained in the theoretical study, English learning in particular, and language learning in general, actually has a common characteristic in the way of acquisition. Language learning is determined by two main aspects of the characteristics of the learners (students) and the environment.

The learners or participants in this training consist of adult teachers for different backgrounds. They are the teachers who must fulfill their duties in teaching learning process as well as in administrative aspects. Physically they have drained enough energy for a week. They are also people who are generally involved in various activities both related to family routines and community programs. Of course, the concentration of learning of trainee teachers is different from those who are pure learners. Whereas in learning a foreign language full concentration is required, especially related to aspects of grammar.

Another factor associated with the participants is the personality factor. Learning a language requires people who have an extroverted personality, people who like to interact and talk with others. With great conversation, 
the vocabulary quickly increases and listening and speaking skills automatically grow fast. In this training they are very active in chatting through online program such as via WhatsApp group on average get high TOEFL score. Unlike introverted people, if not supported by a very strong learning ability, it will be challenging in mastering a foreign language.

In addition to factors derived from the learner, environmental factors also affect English learning outcomes. Those who familiarize themselves in an English-speaking environment will quickly master this language. There are so many ways to familiarize yourself with the English environment, for example: living in an English-speaking community, watching television, videos or English-language movies. In this training the WhatsApp group is actually created to make the participants live in an English-speaking environment. However, not all participants were fully involved in the discussion on WhatsApp.

Participant commitment to participate in this activity becomes the main factors to achieve maximum results. Because indeed all obstacles related to the busyness of teachers, or the language environment can be overcome. The training uses hybrid strategies, mixing of on-line training strategies and training strategies with hands-on training. With this combined method it is actually expected to address the problems faced by teachers during the training maximally. On-line training does require strong commitment from participants. The resource person does not allow for immediate daily active participation in the learning group. Therefore, a suitable strategy is needed to select potential trainees who have a strong commitment to learning and jointly improve their English skills.

\section{Conclusion and Recommendation}

ESA (Engaged-Study-Activate) is a strategy to learn a foreign language based on the theory that the success of language learning is determined by factors involvement in the language environment. For that reason, learning the ideal language is implemented in a country where the language is used as the language of instruction. When such a place of learning cannot be obtained, it is necessary to have an artificial learning environment that gives the atmosphere as if the English learner is in an English-speaking community. This training requires three main activities: engagement, assessment and language activities.

With three main activities, engagement, study and active use of English, training activities can improve English language skills for MTs teachers in Kecamatan Tugu and Ngaliyan. This is evidenced that the acquisition of TOEFL score in post-test with an average of 411, increased significantly from the pre-test score with an average score of 399 .

There is evidence of improving teachers' English proficiency after attending English language proficiency training for Madrasah Tsanawiyah teachers in Tugu and Ngaliyan Sub-districts, so similar training can be conducted for teachers elsewhere.

The recommendation that can be given is English learning with ESA approach is not enough only in the span of two months of assistance, because the activity must be followed up with online mentoring through WA group, as well as through structured routine program from Pergunu. All of these mentoring participants are members of Pergunu Semarang, so that further assistance programs can be planned and implemented.

\section{References}

Allan Collins, et. Al., Cognitive Apprenticeship: Teaching the Craft of Reading, Writing, and Mathematics, Illinois, University of Illinois at Urbana-Champaign, 1987.

Barak, R, The Case for Explicit, Teacher-led, Cognitive Strategy Instruction, Paper presented at the annual meeting of the American EducationalResearch Association, Chicago, IL, 1997

Chaney, A.L, and Burk, T.L., Teaching Oral Communication in Grades K-8, Boston: Allyn \& Bacon, 1998.

Eric Lenneberg, Biological Foundation of Language, John Wiley, New York, 1967.

Fachrurrozi dan Erta Mahyuddin, Pembelajaran Bahasa Asing, Metode Konvensional dan Kontemporer, Jakarta, Bania Publishing, 2011.

Ghazali, Syukur, Pembelajaran Keterampilan Berbahasa, Pendekatan Komunikatif-Interaktif, Jakarta: PT. Retika Aditama, 2010.

Hayriye Kayi, Teaching Speaking: Activities to Promote Speaking in a Second Language, The Internet TESL Journal, Vol. XII, No. 11, November 2006

Harmer, Jeremy, The Practice of English Language Teaching, London: Longman, 1984.

Iskandar wahid dan D. Sunendar, Strategi Pembelajaran Bahasa. Bandung: Remaja Rosdakarya, 2009.

Lightbown \& Spada, How Languages are Learned, 4th Edition, Oxford University Press, 2017.

Maidar, Arsjad, dan Mukti, Pembinaan kemampuan berbicara bahasa Indonesia, Jakarta: Erlangga, 1988.

Paulina dan Melati, Strategi Kognitif, Jakarta: Direktorat Jendral Pendidikan Tinggi Departemen Pendidikan Nasional, 1997.

Robert E. Slavin, Educational Psychology: Theory and Practice in Education, New Jersey: Person Education, 2000.

Reid Bob, Cognitive Strategy Instruction, Lincoln: Dept. of Special Ed \& Communication Disorders, 2006.

Syah, Muhibbin, Psikologi Pendidikan dengan Pendekatan Baru, Bandung, PT. Remaja Rosdakarya, 2002.

Tarigan, H. G, Mendengar Sebagai Suatu Keterampilan Berbahasa, (Bandung: CV. Angkasa, 2008.

Teaching Speaking: Activities to Promote Speaking in a Second Language, The Internet TESL Journal, Vol. XII, No. 11, November 2006.

William, Littlewood, Communicative Language Teaching, Cambridge, Cambridge University Press, 2008. 